\title{
GANDRANG BULO SEBAGAI BAHAN AJAR SENI BUDAYA
}

\author{
Masnaini \\ Guru Seni Budaya \\ SMP Negeri 4 Sungguminasa Kabupaten Gowa \\ Email: masnainibudiman@gmail.com
}

\begin{abstract}
Creative learning and teaching materials need to be prepared to integrate innovative branch of art music, dance and theater. The author raised Gandrang Bulo as teaching materials. Performing arts were developed as teaching materials to integrate the learning of Art and Culture. Problems of research, "How characteristic, model development, application, and feasibility of the final product as an ingredient Gandrang Bulo Festive Culture in SMP Negeri 4 Sungguminasa? The method of research is the research and development. Fundamentals of learning theory and anthropology. Findings include: (1) Characteristics of Gandrang Bulo that integrates elements of music, dance, and theater can be developed as teaching arts materials in SMP, (2) Model Development of Gandrang Bulo as teaching materials by preparation of a draft Cultural Art books, and then tested every draft, revised to a book, validated to produce the final product of teaching materials, (3) integration of the branches of art music, dance and theater effective, because all students are involved play a role according to their talents and interests through collaborative learning approach in developing students who are intelligent, responsible accountable, and participatory; (4) Based on input from the validator, the resulting product as teaching materials Gandrang Bulo Cultural Arts in SMP Negeri 4 Sungguminasa.
\end{abstract}

Keywords: Gandrang Bulo, teaching materials, Cultural Arts.

\begin{abstract}
ABSTRAK
Pembelajaran kreatif dan inovatif perlu disusun untuk memadukan cabang seni musik, tari dan teater. Penulis mengangkat Gandrang Bulo sebagai materi ajar. Seni pertunjukan tersebut dikembangkan sebagai bahan ajar untuk mengintegrasikan pembelajaran Seni Budaya.Permasalahan penelitian, "Bagaimana karakteristik, model pengembangan, aplikasi, dan kelayakan produk akhir Gandrang Bulo sebagai bahan Ajar Seni Budaya di SMP Negeri 4 Sungguminasa? Metode penelitian adalah penelitian dan pengembangan. Landasannya teori pembelajaran dan antropologi. Hasil temuan antara lain: (1) Karakteristik Gandrang Bulo yang mengintegrasikan unsur musik, tari, dan teater dapat kembangkan sebagai bahan ajar Seni Budaya di SMP; (2) Model Pengembangan Gandrang Bulo sebagai bahan ajar Seni Budaya dengan penyusunan draf buku, kemudian diuji coba setiap draf, direvisi menjadi buku, divalidasi sampai menghasilkan produk akhir bahan ajar; (3) Pengintegrasian cabang seni musik, tari dan teater efektif, karena semua siswa terlibat memainkan peran sesuai dengan bakat dan minatnya melalui pendekatan pembelajaran kolaborasi dalam mengembangkan siswa yang cerdas, bertanggung jawab, dan partisipatif; (4)Berdasarkan masukan dari validator, dihasilkan produk Gandrang Bulo sebagai bahan ajar Seni Budaya di SMP Negeri 4 Sungguminasa.
\end{abstract}

Kata kunci: Gandrang Bulo, bahan ajar, Seni Budaya. 


\section{PENDAHULUAN}

Prinsip pendidikan seni dan budaya meliputi pengembangan dimensi kepekaan rasa, peningkatan apresiasi, dan pengembangan kreativitas. Depdiknas (2009:12) menuliskan bahwa bidang seni yang dapat diajarkan pada mata pelajaran seni budaya minimal satu bidang seni (seni rupa, seni musik, seni tari, atau seni teater). Kondisi pembelajaran seni yang memilah-milah cabang seni yang akan diajarkan mempengaruhi psikologi siswa. Siswa sebagai individu mempunyai bakat dan minat seni yang berbeda sehingga dalam mengikuti pelajaran cabang seni tertentu terjadi kondisi belajar karena keterpaksaan. Padahal esensi pembelajaran seni pada pendidikan dasar termasuk Sekolah Menengah Pertama adalah menumbuhkankembangkan minat seni siswa dalam pendidikan nilai etika dan estetika.

Dalam pendidikan seni budaya, aktivitas berkesenian harus memunculkan kekhasan tersebut yang termuat pada pemberian pengalaman mengembangkan konsepsi, apresiasi, dan kreasi. Proses belajar diperoleh melalui upaya eksplorasi elemen, prinsip, proses, dan teknik berkarya dalam konteks budaya masyarakat yang beragam. Gandrang Bulo sebagai salah satu seni pertunjukan dan merupakan aset budaya di Kabupaten Gowa. Keunikan Gandrang Bulo sebagai seni tradisi yang menggabungkan unsur tari, musik dan teater. Pembelajaran terpadu seni pertunjukan pada mata pelajaran Seni Budaya di sekolah belum terlaksana. Integrasi seni pertunjukan merupakan suatu model pembelajaran yang memadukan seni musik, tari dan teater. Oleh karena itu, dipandang perlu dibuat bahan ajar pembelajaran yang kreatif dan inovatif.

Indonesia kaya akan gaya dan bentuk seni pertunjukan. Keberagaman tersebut dipengaruhi oleh banyak faktor, antara lain jumlah penduduk yang besar, etnik, agama, dan pengaruh dari budaya luar. Soedarsono (2002:8117) menggambarkan perkembangan seni pertunjukan Indonesia terdiri dari tujuh masa yaitu: 1) masa pra sejarah, 2) masa pengaru Hindu, 3) masa pengaruh Islam, 4) masa pengaruh Cina, 5) masa pengaruh barat, 6) masa kemerdekaan, 7) masa orde baru dan globalisasi.

Pada masa kekuasaan Jepang, rakyat diperas dan dipaksa bekerja. Jepang menggerakkan pekerja paksa yaitu Romusha.
Mereka dipaksa bekerja di tengah hutan, di tebing, pantai, sungai untuk membuat lapangan terbang dan kubu-kubu pertahanan. (Irsan, 2009). Gandrang Bulo kesenian rakyat Sulawesi Selatan merupakan seni pertunjukan yang berkembang pada masa kolonialisme sebagai media propaganda kepada masyarakat untuk melawan penjajah.

Soedarsono (2003) menguraikan bahwa James R. Brandon dalam bukunya berjudul Theatre in Southeas Asia menjelaskan, bahwa pada akhir abad ke-19 dan awal abad ke-20, ketika negara-negara Eropa dan Amerika Serikat masih menguasai sebagian besar dari negaranegara di Asia Tenggara, para tokoh nasionalis kerap kali menggunakan seni pertunjukan sebagai media untuk membangkitkan semangat rakyat melawan penjajah. Mereka menginginkan sekali adanya dekolonisasi pada negaranya. Genre-genre seni pertunjukan yang banyak dimanfaatkan sebagai media propaganda.

Joyce dan Marsha Weil (1986:2) mengemukakan bahwa model pembelajaran adalah suatu rencana atau pola yang dapat kita gunakan untuk merancang pembelajaran tatap muka di dalam kelas atau dalam latar tutorial dan dalam membentuk material-material pembelajaran termasuk buku-buku, film-film, pita kaset, dan program media computer, dan kurikulum..

Skenario model pembelajaran berupa serangkaian langkah-langkah yang khusus dalam pembelajaran yang akan diperankan secara konkrit oleh siswa dan guru dengan mengkondisikan lingkungan sekitar dan masyarakat serta tradisi lokal sebagai sebagai bahan ajar. Globalisasi menuntut Pendidikan Seni mengembangkan kompetensi yang meliputi pengetahuan (knowledge), keterampilan (skills), dan watak atau karakter (disposition) yang multidimensional. Depdiknas (2007:1) menjelaskan bahwa pendidikan seni memiliki multilingual, multidimensional, dan multikultural. Bahan ajar merupakan informasi, alat dan teks yang diperlukan guru untuk perencanaan dan penelaahan implementasi pembelajaran. Depdiknas (2008) menjelaskan bahwa bahan ajar adalah segala bentuk bahan yang digunakan untuk membantu guru dalam melaksanakan kegiatan belajar mengajar di kelas. Bahan yang dimaksud bisa berupa bahan tertulis maupun bahan tidak tertulis. 
Mengembangkan sensitivitas persepsi indriawi siswa melalui berbagai pengalaman kreatif berkesenian dengan menggunakan tradisi lokal sebagai bahan ajar pembelajaran seni akan menumbuhkembangkan kemampuan apresiasi seni siswa dalam konteks sejarah dan budaya sebagai sarana pembentukan sikap saling toleran dan demokratis dalam masyarakat yang majemuk. Penyusunan bahan ajar perlu disesuaikan dengan tuntutan kurikulum dengan mempertimbangkan karakteristik dan lingkungan sosial peserta didik. Depdiknas (2007) menguraikan bentuk bahan cetak seperti: hand out, buku, modul, lembar kerja siswa, brosur, leaflet, wallchart, Audio Visual seperti: video/film, $V C D$, Audio seperti: radio, kaset, $\mathrm{CD}$ audio, Visual: foto, gambar, model/maket, Multi Media: CD interaktif, computer Based, Internet. Seni Pertunjukan, diartikan sebagai kompak berkesenian siswa yang disajikan dalam bentuk pementasan. Bentuk tarian, nyanyian, dan dialog merupakan bagian utuh dari suatu pentas pertunjukan.

Menurut Koentjaraningrat (2009), setiap kebudayaan suku bangsa terdapat tujuh unsur kebudayaan yang disebut cultural universal, yaitu meliputi: (1) bahasa, (2) sistem pengetahuan, (3) organisasi sosial, (4) sistem peralatan hidup dan teknologi, (5) sistem mata pencaharian hidup, (6) sistem religi, dan (7) kesenian. Soedarsono (2002) mengemukakan bahwa secara garis besar pertunjukan memiliki tiga fungsi, yaitu (1) sebagai sarana ritual; (2) sebagai ungkapan pribadi yang pada umumnya berupa hiburan pribadi; dan (3) sebagai presentasi estetis. Berdasarkan kategori tersebut Gandrang Bulo pada masa kolonialisme berfungsi sebagai ungkapan pribadi berupa kegiatan menghibur diri karena penikmatnya adalah pelakunya sendiri.

Tujuan Penelitian; Mendeskripsikan karakteristik Gandrang Bulo yang dapat dikembangkan sebagai bahan ajar Seni Budaya di SMP Negeri 4 Sungguminasa Kabupaten Gowa; Mendeskripsikan model pengembangan Gandrang Bulo sebagai bahan Ajar Seni Budaya di SMP Negeri 4 Sungguminasa; Mendeskripsikan aplikasi model pembelajaran Gandrang Bulo sebagai bahan Ajar Seni Budaya di SMP Negeri 4 Sungguminasa; Mendeskripsikan kelaya-kan produk Gandrang Bulo sebagai bahan Ajar Seni Budaya di SMP Negeri 4 Sungguminasa

\section{METODE PENELITIAN}

Pendekatan yang digunakan adalah kualitatif. Kelebihan pendekatan kualitatif menurut Alwasilah (2008:192) adanya fleksi-bilitas yang tinggi bagi peneliti ketika menentukan langkah-langkah penelitian. Metode yang digunakan adalah penelitian dan pengembangan (Research and Development). Metode R\&D digunakan karena yang diteliti adalah produk dari pengembangan Gandrang Bulo sebagai bahan ajar Seni Budaya. Untuk menghasilkan bahan ajar tersebut digunakan penelitian yang bersifat analisis kelayakan dan untuk menguji keefektifannya akan dilihat dalam proses pembelajaran. Sugiyono (2009:407) mengemukakan bahwa metode penelitian dan pengembangan adalah metode penelitian yang digunakan untuk menghasilkan produk tertentu, dan menguji keefektifan produk tersebut.

Studi pendahuluan berupaya memahami adanya masalah dan potensi terkait tema penelitian. Selanjutnya pengumpulan data untuk mengumpulkan informasi sebagai bahan yang dapat digunakan untuk merancang atau mendesain produk. Setelah desain produk dikembangkan dilanjutkan dengan validasi desain dengan meminta tanggapan dan masukan dari pihak yang berkompeten. Berdasarkan masukan validator, desain direvisi dilanjutkan dengan uji coba produk di lapangan. Dengan mempertimbangkan hasil uji coba lapangan dan analisis pengamatan, produk direvisi kemudian dibuat produk akhir. 


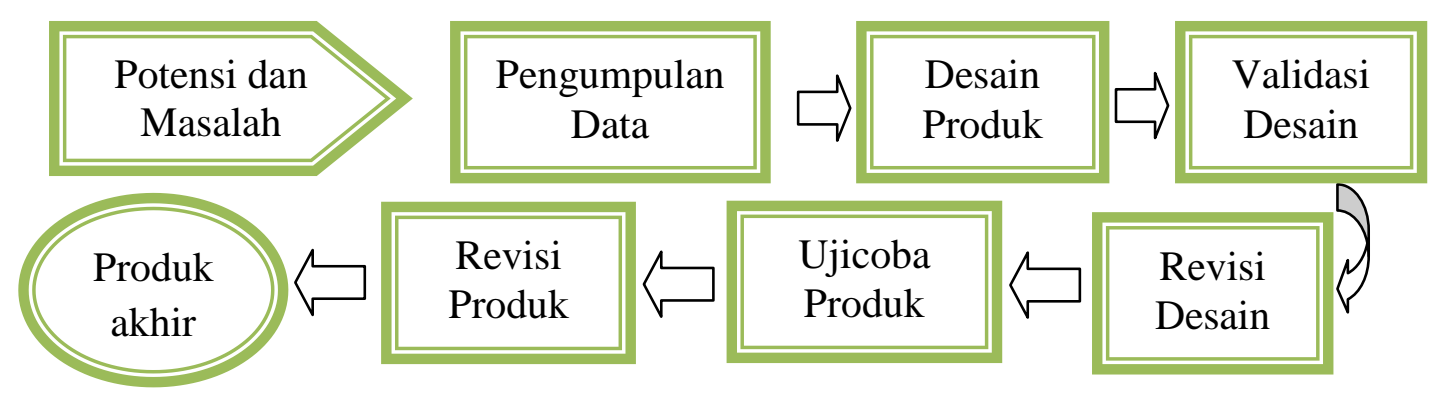

Gambar 1: Desain Penelitian R\&D

Fokus penelitian ini adalah bagaimana mengembangkan gandrang bulo sebagai bahan ajar seni budaya sebagai salah satu seni pertunjukan rakyat Sulawesi selatan yang mengembangan unsure music, tarian dan dialog.

Deskripsi fokus penelitian adalah bagaimana 1). karakteristik Gandrang Bulo yang dapat dikembangkan; 2) Model pengembangan Gandrang Bulo; 3) Aplikasi pembelajaran Gandrang Bulo; 4) Kelayakan produk akhir Gandrang Bulo sebagai bahan Ajar Seni Budaya di SMP Negeri 4 Sungguminasa?

Sumber data diperoleh dari seniman Gandrang Bulo, guru Seni Budaya, dan studi dokumentasi melalui internet dan buku-buku terkait. Lokasi penelitian di SMP Negeri 4 Sungguminasa Kecamatan Somba Opu Kabupaten Gowa. Subjek penelitian adalah siswa kelas VII SMP Negeri 4 Sungguminasa Kabupaten Gowa sebanyak 35 orang

Tahapan Penelitian dengan melakukan kajian pendahuluan meliputi pengumpulan data dengan teknik observasi, wawancara, studi dokumentasi, dan perekaman. Instrumen pengumpulan data menggunakan pedoman observasi model daftar cocok (chek list), pedoman awancara dengan model pertanyaan berstruktur, dan Pedoman analisis melalui model daftar karakteristik pertunjukan/klasifikasi Gandrang Bulo dan uraian hasil analisis.

Melakukan analisis data seperti: Menulis memo, koding, kategorisasi, kontekstualisasi, pajangan Visual, dan pengambilan kesimpulan. Selanjutnya, membuat desain produk, validasi desain, revisi desain, uji coba produk, revisi produk, dan pembuatan produk. Setelah data terkumpul, peneliti melakukan write-up. segera menganalisis data yang diperoleh. Data hasil wawancara dikoding dan dikategorisasikan sebagai berikut: (1) sejarah dan perkembangan, (2) fungsi dan makna, (3), karakteristik pertunjukan, (4) penyajian data , (5) alat musik yang digunakan, (6) lagu-lagu yang dinyanyikan. Studi pustaka juga dilakukan untuk melihat kecenderungan terhadap hasil wawancara. Untuk memperkuat hasil analisis wawancara dan studi pustaka maka kepada subjek penelitian kembali akan dilakukan pengamatan proses aktivitas siswa, mencatat peristiwa dan merekam serta dokumen lain yang mendukung.

\section{HASIL DAN PEMBAHASAN}

\section{Hasil}

Karateristik Gandrang Bulo yang dapat dijadikan bahan ajar Seni Budaya di SMP Negeri 4 Sungguminasa antara lain: musik, pola lantai tari, ragam gerak, dan bentuk teaternya. Musik berupa penggunaan alat musik dan lagu daerah. Gandrang Bulo berupa tarian bambu yang dipadukan dengan alat musik bambu, gendang dan biola. Instrumen musik antara lain: Kattokatto,Gandrang caddi, dan Kecapi. Tempo musiknya cepat mengalun riang disertai lirik lagu khas Makassar mengiringi gerak tangan dan kaki pemain yang cepat dan rancak. Lagu-lagu terdiri dari lagu dolanan dalam syair bahasa Makassar. Nyanyian dipilih sesuai dengan tema pertunjukan. Pola inti tari terdiri dari: a. Ragam gerak utama; Gerak Si kali-kali, gerak Tabe, gerak Berlutut, $\mathrm{Ma}$ 'Rencong-rencong, gerak Kondo-kondo. b. Pola lantai utama; Komposisi Tabe (penghormatan), Komposisi Tassimbung (berpencar), Komposisi Kondo-kondo (gerak lucu), Komposisi Ma' Rencong-rencong (Bulan Sabit). Pola lantai Gandrang Bulo terdiri dari: a. Komposisi Tabe, b. Komposisi Tassimbung (berpencar), c. Komposisi Kondo-kondo (gerak Lucu). 


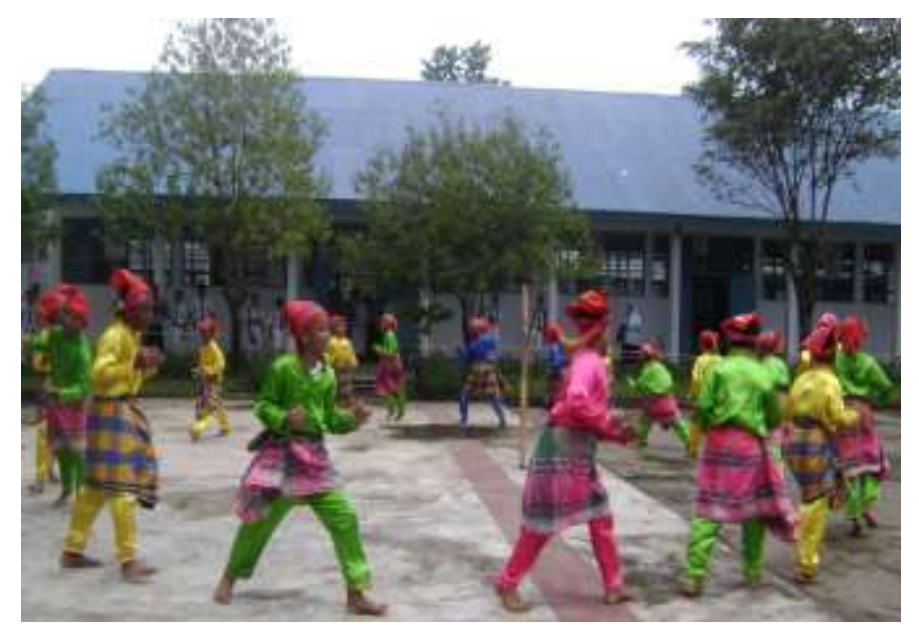

Gambar 2. Gerak Ma'Rencong-rencong

Model Pengembangan Gandrang Bulo sebagai Bahan Ajar Seni Budaya . Model pembelajaran menggunakan pendekatan kontekstual. Konsep belajar ini fokus pada aktivitas siswa belajar secara bersama dalam kegiatan bermain musik, tari dan teater sebagai pemain dalam pembelajaran Gandrang Bulo. Pembelajaran terpadu dan pembelajaran kolaborasi berlangsung dan dikemas dengan kegiatan siswa 


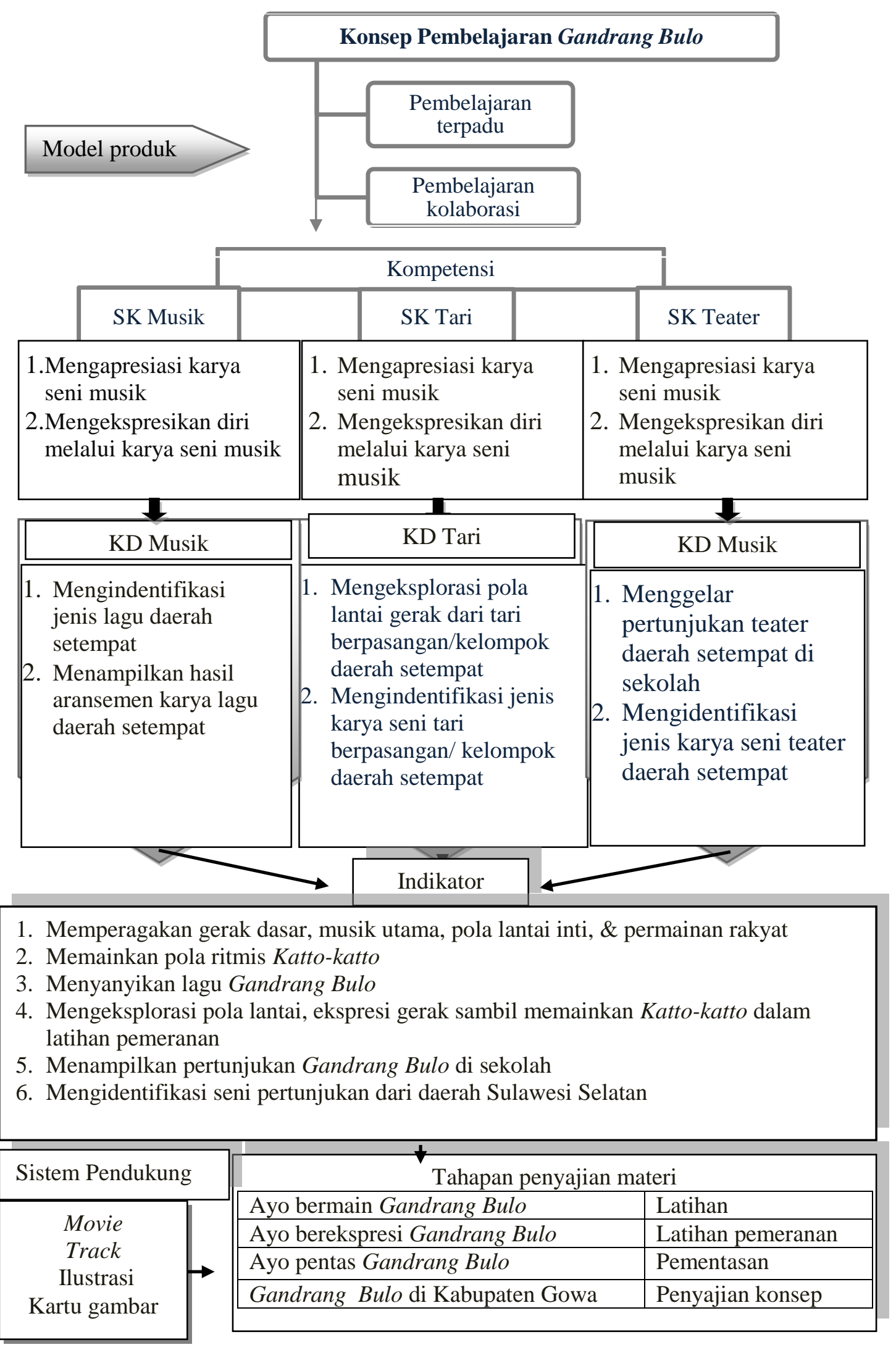

Gambar 3: Model pengembangan Gandrang Bulo sebagai bahan ajar 
Berikut Tahapan penyusunan model pengembangan Gandrang Bulo:

1) Penyusunan bahan ajar terdiri dari: mengklasifikasikan standar kompetensi dan kompetensi dasar yang relevan, indikator, tahapan penyajian materi, bentuk penyajian dan sistem pendukung penyajian.

2) Penyajian draf buku Gandrang Bulo sebagai bahan ajar. Draf terdiri dari tiga bab yakni: a) Gandrang Bulo di Kabupaten Gowa, bab ini mendeskripsikan konteks pertunjukan seni di Kabupaten Gowa, pengertian, fungsi, perkembangan, bentuk, karakteristik, busana, panggung Gandrang Bulo; b) Mengenal Gandrang Bulo, bab yang menjelaskan tentang pertunjukan Gandrang Bulo, mengenal permainan rakyat, musik Gandrang Bulo, tari Gandrang Bulo, dan teater Gandrang Bulo; c) Ayo bermain Gandrang $B u l o$, terdiri dari tahapan berlatih, penyajian, dan pementasan Gandrang Bulo;

3) Penyajian draf per draf dalam pembelajaran yaitu aplikasi bahan ajar terdiri dari tiga tahap yakni: a) Tahap pertama, disajikan draf satu pada pertemuan pertama; b) Tahap dua, disajikan draf kedua sebanyak tiga kali pertemuan; dan c) Tahap tiga, penyajian draf ketiga sebanyak dua kali pertemuan;

4) Diadakan pengembangan model dengan merevisi buku, agar perbaikan bahan ajar dapat mencapai hasil yang lebih maksimal. Berdasarkan analisis pengamatan selama uji coba dan evaluasi pembelajaran berlangsung tampak siswa hanya diam. Aktivitas siswa cenderung pasif dalam mengikuti pelajaran yang bersifat teoritis pada pertemuan awal, namun sebaliknya ketika memasuki pertemuan yang bersifat praktek semua siswa nampak antusias. sehingga draf awal buku yang menyajikan konsep terlebih dulu sebelum praktek bermain direvisi menjadi siswa bermain sebelum belajar konsep Gandrang Bulo. Hasil revisi terdiri dari empat bagian yaitu: a) Ayo bermain Gandrang Bulo, berisi kegiatan antara lain: (1) Ayo belajar ekspresi gerak, gerak merupakan unsur utama karena gerak dipadukan menjadi sebuah rangkaian tari. Ekspresi gerak antara lain gerak mata. kepala, tangan/ lengan, tubuh, pinggul dan kaki; (2) Kondo-kondo, gerakan lucu yang dilakukan oleh pemain Gandrang Bulo antara lain: Si Denge-denge, Si Tobotobo, Si Tolo, Si Toa-toa, Si Monyet, dan sebagainya; (3) Ayo belajar instrumen Kattokatto, musik Gandrang Bulo yang menampilkan pemain dengan instrumen bambu (Katto-katto) di tangan; dan 4) Latihan pola lantai; b) Ayo berekspresi Gandrang Bulo, kegiatan berlatih yang terdiri dari: (1) Latihan gerak dasar tari, berlatih gerak inti dan mengembangkan ke gerak yang lain; (2) Memilih permainan rakyat, permainan tradisional salah satu kegiatan yang dapat dijadikan materi dalam pertunjukan Gandrang Bulo; (3) Penyajian terdiri dari: Eksplorasi pola lantai, latihan pertunjukan Gandrang Bulo; c) Ayo pentas Gandrang Bulo, pementasan meliputi: (1) Pengorganisasian pementasan; (2) Persiapan pementasan; (3) Pelaksanaan pementasan; dan (4) Evaluasi pementasan, dan d) Gandrang Bulo di Kabupaten Gowa, konsep keberadaan Gandrang bulo di masyarakat Gowa

5) Validasi, penilaian atau tanggapan dari ahli, guru dan siswa terhadap bahan ajar yang telah disusun;

6) Produk, berupa buku Gandrang Bulo sebagai bahan ajar Seni Budaya di SMP Negeri 4 Sungguminasa.

Aplikasi Pembelajaran Gandrang Bulo sebagai Bahan Ajar Seni Budaya

Aplikasi pembelajaran Gandrang Bulo sebagai bahan ajar Seni Budaya dilaksanakan selama beberapa kali pertemuan. Peran siswa adalah sebagai subyek belajar yang memperoleh pengalaman, meniru model dan sebagai tutor bagi temannya yang lain. Sementara guru berperan sebagai model, memberi balikan, memotivasi, menciptakan kondisi agar belajar berlangsung secara optimal.

Kelayakan Produk Gandrang Bulo sebagai Bahan Ajar Seni Budaya

Peneliti melakukan wawancara kepada beberapa siswa setelah kegiatan pementasan. Perpaduan cabang seni musik, tari dan teater melalui pembelajaran yang terintegrasi dan dikembangkan secara interaktif serta rekreatif memberikan pengalaman berharga bagi siswa. Wakil kepala sekolah merespons positif kegiatan siswa selama penelitian berlangsung. Kepedulian mereka memberikan masukan dan kemudahan serta memfasilitasi baik saat pengumpulan data, pelaksanaan uji coba sampai kegiatan 
pementasan selesai merupakan dukungan yang sangat berharga dalam kelancaran uji lapangan. Kerjasama peneliti dengan guru mitra dan tamu model dalam mengaplikasikan Gandrang Bulo sebagai bahan ajar Seni Budaya memberikan dinamika pembelajaran yang menyenangkan. Siswa terlihat lebih aktif, riang, dan kooperatif. Guru mitra merasa memperoleh banyak manfaat dari penelitian ini. Komentarnya bahwa selama ini pembelajaran monoton dan konvensional, namun dengan kegiatan ini ada peningkatan dari segi keterlibatan serta partisipasi aktif siswa.

Berdasarkan masukan dari ahli, guru dan siswat, maka setting latar belakang yang mengganggu atau tidak sesuai baik pada illustrasi, font size maupun isi buku diperbaiki sesuai pedoman revisi penilaian buku, sedangkan masukan siswa tentang penggunaan warna yang berlebihan di dalam isi bahan ajar direvisi kembali dan disederhanakan. Permainan rakyat yang ditampilkan seharusnya menggunakan foto asli. Setelah melewati semua tahap penelitian, maka produk akhir Gandrang Bulo sebagai bahan ajar Seni Budaya di SMP Negeri 4 Sungguminasa telah dihasilkan.

\section{Pembahasan}

\section{Konsep Kesenian Gandrang Bulo}

Gandrang Bulo, kesenian rakyat yang menggabungkan unsur musik, tarian dan dialog kritis yang kocak. Perkembangannya terdiri dari dua fase. Fase pertama adalah Gandrang Bulo klasik sedangkan fase kedua pada tahun 1942 saat penjajahan Jepang disebut Gandrang Bulo 1942. Fase pertama sekedar tarian yang diiringi oleh gendang. Seiring dengan perjalanan waktu tarian ini mengalami perubahan yakni ada tambahan iringan begitu pula lagu-lagu jenaka, dialog-dialog humor namun sarat kritik dan ditambah gerak tubuh yang mengundang tawa.

Perkembangan fungsi Gandrang Bulo telah mengalami pergeseran sesuai dengan jaman dan masyarakat pendukungnya. Gandrang Bulo klasik pada masa Kerajaan Gowa berfungsi sebagai seni hiburan bagi masyarakat. Gandrang Bulo Sebagai media penyadaran rakyat akan buruknya penjajahan berfungsi sebagai alat propaganda seniman melawan penjajah dan sarana hiburan bagi pribumi saat tiba waktu istirahat dari kerja paksa. Karateristik Gandrang Bulo yang dapat dijadikan bahan ajar Seni Budaya di SMP Negeri 4 Sungguminasa antara lain: musik, pola lantai tari, ragam gerak, dan bentuk teaternya. Musik berupa penggunaan alat musik dan lagu daerah. Gandrang Bulo berupa tarian bambu yang dipadukan dengan alat musik bambu, gendang dan biola. Huda (2007) menjelaskan bahwa bentuk awal kesenian ini, sudah ada sejak jaman raja-raja Gowa, hanyalah tarian bambu hasil kombinasi alat musik bambu, gendang dan biola. Gandrang Bulo ini lazim disebut dengan Gandrang Bulo Ilolo gading, yang dinisbatkan pada salah satu perlengkapan musiknya yang terbuat dari bambu lolo gading (sejenis bambu tertentu).

\section{Aspek Pedagogik}

Pendidikan seni budaya diajarkan di sekolah karena keunikan, kebermaknaan dan kebermanfaatan terhadap kebutuhan perkembangan peserta didik, yang terletak pada pemberian pengalaman estetik dalam bentuk kegiatan berekspresi/berkreasi dan berapresiasi. Ativitas didukung oleh beberapa faktor, antara lain: (1) Siswa, komponen siswa terdiri dari motivasi, bakat, minat, intelegensi, sikap perasaan dan keadaan psikis serta fisik; (2) Penggunaan kurikulum; (3) Media dan alat peraga pembelajaran,; (4) Sarana dan prasarana dan tak kalah pentingnya adalah guru. Bahan ajar tersebut diterapkan dengan menggunakan Pendekatan Kontekstual. Menurut Nurhadi (2004) pembelajaran kontekstual adalah konsep belajar dimana guru menghadirkan dunia nyata ke dalam kelas dan mendorong siswa membuat hubungan antara pengetahuan yang dimilikinya dengan penerapannya dalam kehidupan mereka sehari-hari.

Masa usia sekolah pendidikan dasar dan menengah merupakan masa remaja yang banyak menarik perhatian, dimana peserta didik memiliki sifat-sifat khas yang harus dipertimbangkan dalam mengembangkan kurikulum. Ruhimat (2009:28) menjelaskan bahwa pemahaman tentang perkembangan peserta didik sebagaimana yang diuraikan berimplikasi terhadap pengembangan kurikulum, antara lain: 1) Setiap peserta didik hendaknya diberi kesempatan untuk berkembang sesuai dengan bakat, minat, dan kebutuhannya; 2) Di samping disediakan pelajaran yang sifatnya umum (program inti) yang wajib dipelajari setiap anak di sekolah, juga disediakan pelajaran pilihan yang sesuai dengan minat anak; 3) Lembaga pendidikan hendaknya menyediakan bahan ajar baik yang bersifat kejuruan maupun 
akademik. Bagi anak yang berbakat di bidang akademik diberi kesempatan untuk melanjutkan studi ke jenjang pendidikan berikutnya; 4) Kurikulum memuat tujuan-tujuan yang mengandung aspek pengetahuan, nilai/sikap, dan keterampilan yang menggambarkan pribadi yang utuh lahir dan batin.

Berdasarkan pemahaman tersebut, maka peneliti memilih model pembelajaran yang sesuai dengan perkembangan siswa SMP kelas VII dan memberikan pengalaman nyata dalam berkarya seni. Pendekatan kontekstual yang diterapkan adalah: 1) Model pembelajaran terpadu,dan 2) Model pembelajaran kolaborasi.

\section{SIMPULAN DAN SARAN}

Berdasarkan hasil dan pembahasan penelitian disimpulkan bahwa karateristik Gandrang Bulo yang dapat dijadikan bahan ajar Seni Budaya di SMP Negeri 4 Sungguminasa antara lain: musik, pola lantai tari, ragam gerak, dan bentuk teaternya; Model pengembangan Gandrang Bulo berupa pembelajaran terpadu dan pembelajaran kolaborasi yang berlangsung dan dikemas dengan kegiatan siswa melalui pendekatan kontekstual: Aplikasi pembelajaran Gandrang Bulo sebagai bahan ajar Seni Budaya dapat dilakukan; dan berdasarkan masukan dari ahli, guru dan siswa kelayakan produk Gandrang Bulo sebagai bahan Ajar Seni Budaya di SMP Negeri 4 Sungguminasa memberikan manfaat tersendiri bagi pengembangan pembelajaran Seni Budaya yang lebih variatif dan rekreatif .

Dinas pendidikan, Pemuda, dan Olahraga Kabupaten Gowa, penentu kebijakan pendidikan di daerah Gowa agar memikirkan pengembangan dan pelestarian seni tradisi daerah setempat sebagai potensi lokal. Pelestarian dan pewarisan nilai budaya lokal melalui inovasi pembelajaran seni tradisi daerah setempat di sekolah, maka hendaknya dibarengi dengan ketersediaan perangkat kurikulum yang tepat, peningkatan kelengkapan fasilitas pembelajaran, pendidikan dan pelatihan guru. Bagi peneliti, hendaknya Gandrang Bulo dan seni tradisi lainnya sebagai aset daerah dikembangkan melalui penelitian dalam upaya pengembangan dan pelestarian seni tradisi tersebut.
Lembaga Pendidik dan Tenaga Kependidikan sebagai pengelola dan pencetak guru Seni Budaya di perguruan tinggi hendaknya mengoptimalkan lulusannya sebagai pendidik sekaligus pemikir kebudayaan. Mengembangkan kegiatan penelitian dan pengembangan berbagai inovasi model pembelajaran Seni Budaya dalam upaya meningkatkan mutu pendidikan.

\section{DAFTAR RUJUKAN}

Alwasilah, A. C. (2009). Pokoknya Kualitatif. Dasar-Dasar Merancang dan Melakukan Penelitian Kualitatif. Jakarta: Pustaka Jaya.

Depdiknas (2007). Model Silabus dan Rencana Pelaksanaan Pembelajaran. Jakarta: BSNP Depdiknas.

Depdiknas 2009. Buku Saku Kurikulum Tingkat Satuan Pendidikan (KTSP) Sekolah Menengah Pertama. Jakarta: Depdiknas Dirjen Manajemen Pendidikan Dasar dan Menengah Direktorat Pembinaan Sekolah Menengah Pertama.

Departemen Pendidikan Nasional. (2008). Pengembangan Bahan Ajar dan Media. Jakarta: Departemen Pendidikan Nasional.

Huda, M. N. (2007). Gandrang Bulo Kritik Kocak Seniman Rakyat. [Online]. Tersedia:

http://nurulhuda.wordpress.com/2007/07 /06/ gandrang-bulo-kritik-kocakseniman-rakyat/Gandrang Bulo, Kritik Kocak Seniman Rakyat. (18 Maret 2010)

Irsan, A. (2009). Perjuangan Bangsa Indonesia Melawan Penjajah. [Online]. Tersedia:http://webcache.googleusercont ent.com. Update 20 Mei 2010.

Joice. B., weil. M., Calhoun. E. (2009). Models of Teaching Model-model Pengajaran. Yogyakarta. Pustaka Pelajar.

Koentjaraningrat. (2009). Pengantar Ilmu Antropologi. Jakarta. Rineka Cipta

Nurhadi, Yasin. B, dan Gerrand. A.S. (2004). Pembelajaran Kontekstual dan Penerapannya dalam KBK. Universitas Negeri Malang.

Ruhimat. T, dan Alinawati. (2009). PrinsipPrinsip Pembelajaran. Kurikulum \& Pembelajaran. Bandung. Jurusan Kurikulum dan Teknologi Pendidikan 
Fakultas Ilmu Pendidikan Universitas Pendidikan Indonesia.

Soedarsono, R. M. (2002). Seni Pertunjukan Indonesia di Era Globalisasi. Jogyakarta. Gadjah Mada University Press.

Soedarsono, R. M. (2003). Seni Pertunjukan dari Perspektif Politik, Sosial, dan Ekonomi. Jogyakarta. Gadjah Mada University Press.

Sugiyono. (2009). Metode Penelitian Pendidikan Pendekatan Kuantitatif, Kualitatif, dan $R \& D$. Bandung. Alfabeta. 